\title{
Incidence of Viruses Infecting Sweetpotato in Tanzania
}

\author{
Fred Tairo and Alois Kullaya, Mikocheni Agricultural Research Institute, P.O. Box 6226, Dar-es-Salaam, Tanzania; \\ and Jari P. T. Valkonen, Department of Plant Biology and Forest Genetics, Box 7080, SLU, SE-750 07 Uppsala, \\ Sweden, and Department of Applied Biology, University of Helsinki, Finland
}

\begin{abstract}
Tairo, F., Kullaya, A., and Valkonen, J. P. T. 2004. Incidence of viruses infecting sweetpotato in Tanzania. Plant Dis. 88:916-920.

A survey for incidence of sweetpotato viruses was carried out in the three sweetpotato-producing districts (Bukoba, Misungwi, and Tarime) in the Lake Victoria basin and in the Indian Ocean coastal zone (Bagamoya on the mainland and Unguja on Zanzibar Island) in Tanzania in March and April 2003. A total of 170 plants from 43 sweetpotato fields were collected, established in an insect-proof screenhouse, and tested for viruses by nitrocellulose membrane enzyme-linked immunosorbent assay (NCM-ELISA). Scions from symptomless plants were grafted onto Ipomoea setosa, a nearly universal indicator plant for sweetpotato viruses, and leaves were tested by NCM-ELISA. Results were confirmed in several seropositive plants by cloning and partial sequencing of the viruses. Sweet potato feathery mottle virus (SPMFV), Sweet potato mild mottle virus, Sweet potato chlorotic stunt virus (SPCSV), and Sweet potato chlorotic fleck virus were detected serologically in single or mixed infections. Frequencies of occurrence of these viruses as determined by serological detection showed SPMFV to be the most prevalent virus in all the surveyed districts. Our study revealed a higher incidence and diversity of viruses in the Lake Victoria basin compared with the Indian Ocean coastal area. These results represent the first survey for sweetpotato viruses in Tanzania using accurate detection methods.
\end{abstract}

Additional keywords: cultural practices, Ipomoea batatas, RT-PCR

Sweetpotato, Ipomoea batatas (L.) Lam., is an important subsistence food crop grown in almost all agroecological zones of Tanzania. It ranks fourth in food production in Tanzania after maize, cassava, and bean. It is considered by many Tanzanian farmers as a household food security crop that prevents food shortage before the next harvest of maize or other staple food (10). Sweetpotato is drought tolerant and can be piece-meal harvested over an extended period (3).

Sweetpotato production is constrained by relatively few biotic factors, the most important of which are weevils and viruses (14). Virus diseases alone can cause yield reductions of 56 to $98 \%$ (15). In East Africa, severe sweetpotato virus disease (SPVD), characterized by stunting of plants and heavy yield losses, has been reported in Uganda since $1944(11,15)$ and later in Kenya, Tanzania, Rwanda, Burundi, Malawi, and the Transvaal province

Corresponding author: J. Valkonen

E-mail: jari.valkonen@vbsg.slu.se

Accepted for publication 14 April 2004.

Publication no. D-2004-0706-01R

(C) 2004 The American Phytopathological Society of South Africa (18). A few previous studies have reported on incidence of SPVD in the Lake Victoria basin, the major sweetpotato-growing zone in Tanzania, based on foliar symptoms $(1,10)$. In a recent study, Sweet potato feathery mottle virus (SPFMV) was detected and partially characterized at the sequence level from two sweetpotato plants displaying SPVD in Bagamoyo district at the Indian Ocean costal zone (17).

However, observation of symptom expression $(2,4,15)$ but no comprehensive studies utilizing accurate detection methods have been directed toward the occurrence of sweetpotato viruses in Tanzania. The application of serological methods with currently available antisera for several sweetpotato viruses, augmented with molecular techniques, offers reliable diagnosis. The aim of this study was to provide an understanding of the occurrence of sweetpotato viruses and their possible association with agricultural practices in the sweetpotato-growing areas in Tanzania.

\section{MATERIALS AND METHODS}

Survey and sweetpotato sampling. In all, 240 plants were sampled from 43 sweetpotato fields in each of the five districts of Tanzania that represent three dif- ferent agroecological zones (Fig. 1). The zones were (i) Bukoba (rural), Misungwi, and Tarime districts in the Lake Victoria zone, (ii) Bagamoyo district in the coastal region, and (iii) Unguja district on the Zanzibar Island of the Indian Ocean. These areas were selected based on their importance in sweetpotato production. In Bukoba and Tarime, the surveyed areas were chosen close to the borders of Uganda and Kenya, respectively, where sweetpotato viruses and virus diseases recently were studied $(6,15)$.

Most of the sweetpotato farmers in the surveyed areas were women. They grew sweetpotato as mixed cropping with cassava, maize, and bean or cowpea. Monoculture of sweetpotato was more common in Bagamoyo (Fig. 1) than in other surveyed districts and typically included several sweetpotato cultivars grown in a field plot. Cultivars were identified by the name given to them by farmers or, if unknown, assigned the name of the village. A total of 112 cultivar names were recorded from the surveyed areas. Cvs. Polista, Simama, Sinia, and Kalamu ya Nyerere were common around the Lake Victoria zone, whereas Mavuno, Karoti, Kikombe, Ukerewe, and Kishikiro were common to Bagamoyo and Unguja. Cultivars with high yield, high dry matter content, and earliness were preferred regardless of susceptibility to diseases.

Fields for sampling were selected along rural roads at $2-\mathrm{km}$ intervals. In each field, four sweetpotato plants with virus-like symptoms and two symptomless plants were picked randomly along a straight line over the field. From each plant, two to three cuttings were taken. Each farmer was asked the source of his or her planting materials, planting material preparation method, selection criteria for planting materials, and whether she or he recognized apparent virus symptoms as being due to a disease, insect attack, or weather effect. In some fields, farmers were given an opportunity to pick a plant that they regarded as a good source of planting material.

All sweetpotato cuttings were established in an insect-proof screenhouse at Mikocheni Agricultural Research Institute (MARI), Dar-es-Salaam. This allowed observation of symptoms for all sampled vines in a similar environment and carry- 
ing out subsequent virus disease diagnostic studies.

Virus detection. A disc ( $1 \mathrm{~cm}$ in diameter) was taken from a leaf at the top, middle, and lower part of the stem from each plant and used for routine serological testing of viruses with nitrocellulose membrane enzyme-linked immunosorbent assay (NCM-ELISA; 5). Virus-specific polyclonal antibodies to SPFMV, Sweet potato chlorotic stunt virus (SPCSV), Sweet potato mild mottle virus (SPMMV), and Sweet potato chlorotic fleck virus (SPCFV), as well as NCM strips spotted with sap from virus-positive and noninfected control plants, were kindly provided by the International Potato Center (CIP, Lima, Peru). Visual assessment of the development of a purple color on the sample spots was used to identify virus-positive samples (8).

Graft-transmission experiment. All sweetpotato plants with symptoms suggestive of virus infection but which tested negative to all antisera used were grafted onto Ipomoea setosa Kerr. Similarly, selected plants with single or mixed infection with SPFMV, SPMMV, SPCSV, and SPCFV were included in the grafting experiments. $I$. setosa is a sensitive indicator plant for sweetpotato viruses (4) and higher virus titers and more apparent symptoms can be observed compared with many sweetpotato cultivars. Also, different viruses and virus complexes could be compared directly to avoid symptom differences due to genetic differences between sweetpotato cultivars (15). The grafted I. setosa plants then were observed for symptoms and tested for viruses using NCM-ELISA.

Reverse-transcription polymerase chain reaction. Two sweetpotato plants from each district that tested positive for SPFMV, SPMMV, or SPCSV in NCMELISA also were tested by reverse-transcription polymerase chain reaction RTPCR using virus-specific primers. Alternatively, the leaves of I. setosa shoots grafted with these plants were tested. Total RNA was extracted using TRIzol Ls reagents (InVitrogen Ltd., Groningen, The Netherlands) according to the manufacturer's instructions. The quality of the extracted total RNA was evaluated by electrophoresis in an agarose gel (1\%) stained with ethidium bromide and visualized under UV light. The cDNA was synthesized from total RNA using Moloney murine leukemia virus reverse transcriptase (mMLV-RT; Promega Corp., Madison, WI) according to the manufacturer's instructions. For SPFMV and SPMMV, known members of the family Potyviridae that have a poly-A tail at the $3^{\prime}$ end of the genome (19), cDNA was synthesized with an oligo(dT) primer. Subsequently, PCR amplification of viral sequences was carried out with forward (F) and reverse $(\mathrm{R})$ primers described in previous studies: CP 106 (F) and UTR 34 (R) for SPFMV (13), and MMB1 (F) and an oligo(dT) primer (R) for SPMMV (16). For SPCSV, cDNA was synthesized with the primer CL 43L and amplification viral sequence by PCR was carried out with the primers CL43U (F) and CL 43L (R), as previously described (9). The PCR reaction mixture $(50 \mu \mathrm{l})$ contained $1 \times$ PCR buffer, $1.5 \mathrm{mM} \mathrm{MgCl}_{2}, 0.2 \mathrm{mM}$ dNTPs, $0.2 \mu \mathrm{M}$ forward and reverse primers, 2.5 units of Ta $q$ DNA polymerase (MBI Fermentas, St. Leon-Rot, Germany), and $3 \mu \mathrm{l}$ of viral cDNA. Amplification was carried out in a Thermocycler (MJ Research Inc., Watertown, MA) using the following program: an initial denaturation step at $94^{\circ} \mathrm{C}$ for 2 min followed by 34 cycles at $94^{\circ} \mathrm{C}$ for 30 $\mathrm{s}, 55^{\circ} \mathrm{C}$ for $30 \mathrm{~s}, 72^{\circ} \mathrm{C}$ for $1 \mathrm{~min}$, and the final extension step of $72^{\circ} \mathrm{C}$ for $20 \mathrm{~min}$. The PCR products were separated by electrophoresis in a $1 \%$ agarose gel containing ethidium bromide and then visualized under UV light.

Virus incidence. Virus scores (1 for positive, 0 for negative detection) based on the serological results were used to establish the incidence of viruses per district. A computer program (SPSS 9.0; SPSS Inc., Chicago) was used to make a descriptive analysis on frequencies of occurrence of each virus, both in single and mixed infections.

\section{RESULTS}

Incidence of sweetpotato viruses. In all, 170 sweetpotato plants were established successfully in the screenhouse from cuttings collected in the field. Of these, 97 plants displayed virus-like symptoms and $84(87 \%)$ reacted positively with at least one of the four virus-specific antisera used for NCM-ELISA. Thirteen plants were negative to all antisera used and represented virus-like diseases of unidentified etiology (DUE; Fig. 2). Of the 73 symptomless plants, 35 (48\%) were seropositive for viruses, including SPFMV (25 plants), SPMMV (2 plants), SPCSV and SPCFV (1 plant each), mixed infection with SPFMV and SPMMV (4 plants), or mixed infection with SPCSV and SPMMV (2 plants). Thus, 119 seropositive plants were found among the 170 plants tested, and 29 seropositive plants $(23 \%)$ were infected with more than one virus. The most common of the multiple infections were dual infection with SPFMV and SPCSV, followed by mixed infections with SPFMV and SPMMV, or SPMMV and SPCSV (Fig. 2). Mixed infection with SPFMV, SPMMV, and SPCSV was detected in two plants.

The most frequently detected virus among the 119 seropositive plants was SPFMV (85\%). It was the only virus in $56 \%$ of the 132 symptomatic plants (Fig. 2).

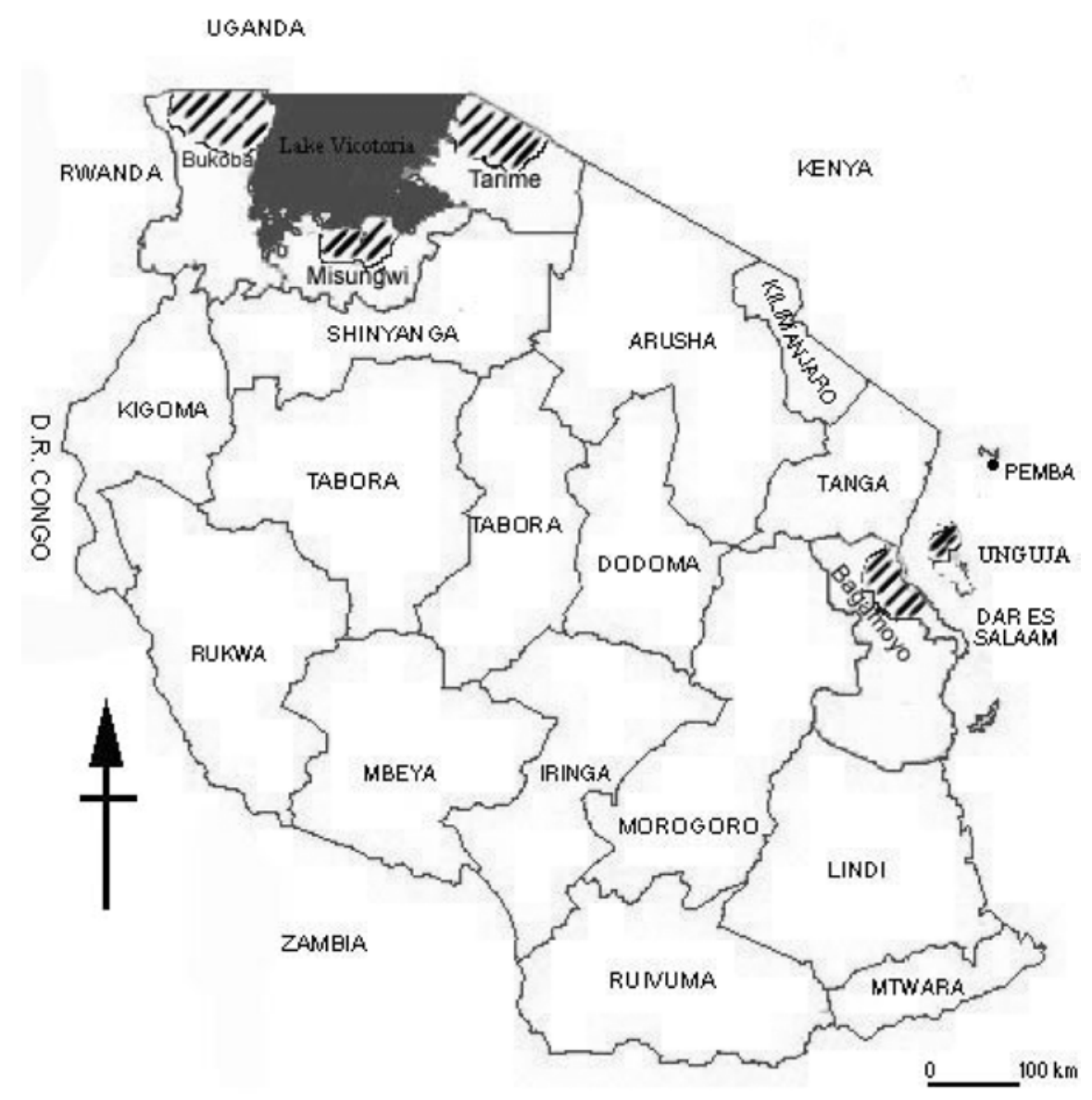

Fig. 1. Map of Tanzania showing the five surveyed districts representing three agroecological zones: the Lake Victoria basin (Bukoba, Misungwi, and Tarime), mainland at the coast of the Indian Ocean (Bagamoyo), and the Zanzibar Island (Unguja). 


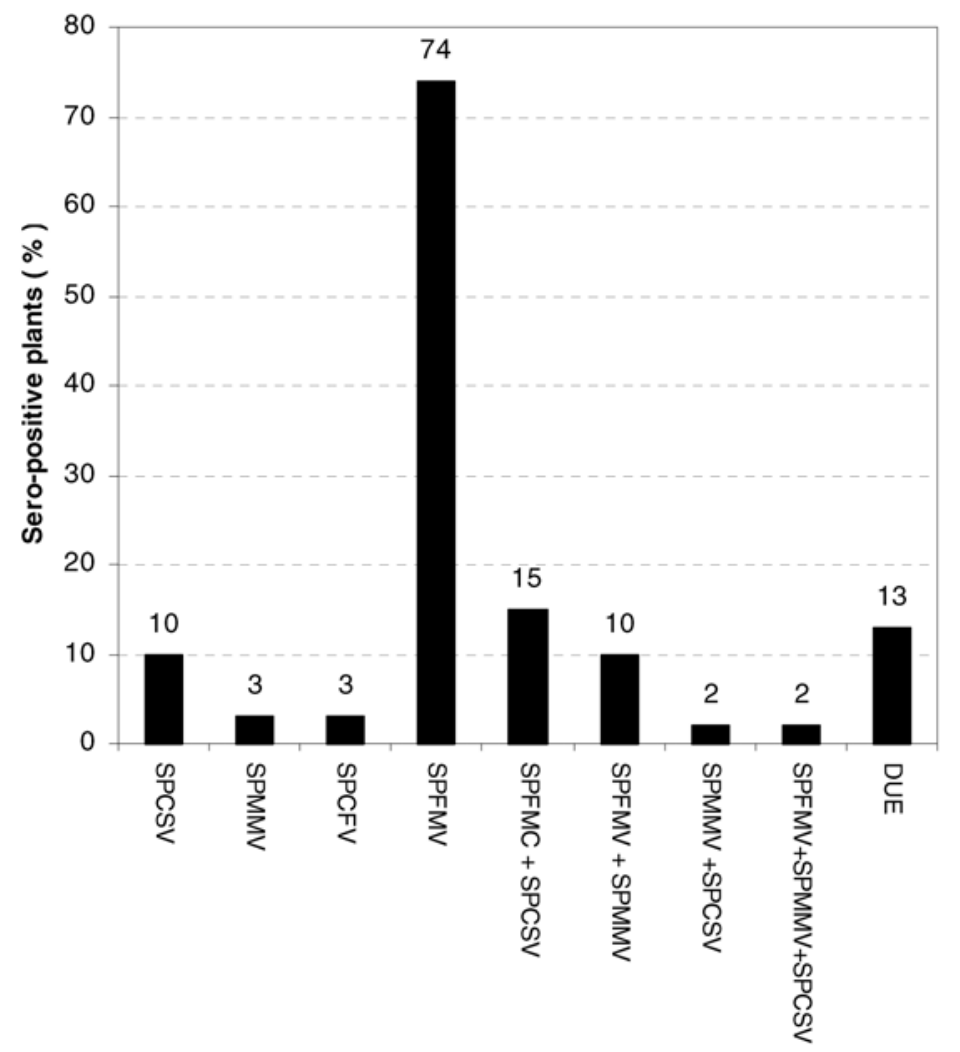

Fig. 2. Percentage of single and mixed virus infections detected by nitrocellulose membrane enzymelinked immunosorbent assay in a total of 132 sweetpotato plants collected from five districts of Tanzania, and which displayed virus-like symptoms when grown in a screenhouse. The number of seropositive plants is indicated above each bar. SPCSV $=$ Sweet potato chlorotic stunt virus, SPMMV = Sweet potato mild mottle virus, SPCFV = Sweet potato chlorotic fleck virus, SPFMV = Sweet potato feathery mottle virus, and DUE = virus-like disease of unknown etiology.

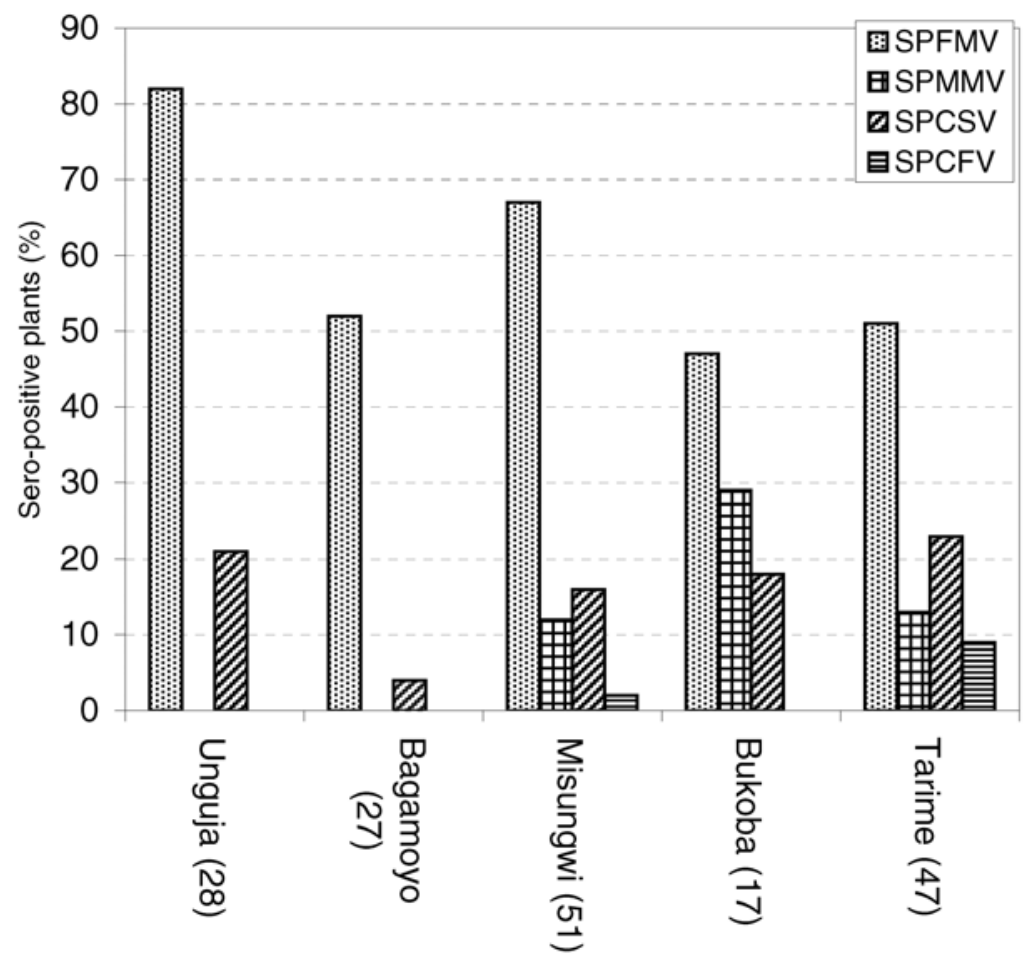

Fig. 3. Incidence of sweetpotato viruses in a total of 170 plants collected from five sweetpotatogrowing districts in Tanzania, established in a screenhouse, and subsequently tested for viruses by nitrocellulose membrane enzyme-linked immunosorbent assay. The number in brackets indicates the number of plants tested from the respective district. SPFMV = Sweet potato feathery mottle virus, SPMMV = Sweet potato mild mottle virus, SPCSV = Sweet potato chlorotic stunt virus, and SPCFV = Sweet potato chlorotic fleck virus.
SPFMV was common in all districts surveyed (Fig. 3) and was found in 47 to $82 \%$ of the plants, depending on the district (Fig. 3). SPCSV was detected with relatively similar frequencies (16 to $23 \%$ ) in four districts (Fig. 3) and was the only virus detected in $7.6 \%$ of the symptomatic plants (Fig. 2). It was rare in the Bagamoyo district in the Indian Ocean coastal zone, where it was found in only 1 of 27 plants tested (Fig. 3). SPMMV and SPCFV were detected only in the Lake Victoria zone. In most cases, SPMMV was found co-infecting plants with SPFMV (Fig. 2), and its frequency of occurrence in the plants assayed was 12 to $29 \%$ (Fig. 3). SPCFV was found in four plants in Tarime and one plant in Misungwi (Fig. 3).

Apart from using virus-specific antisera in NCM-ELISA for virus detection, SPFMV, SPCSV, and SPMMV also were detected by RT-PCR in 10 seropositive plants, in which two or all three of the viruses occurred in mixed infection. With each virus-specific primer pair, a single band corresponding to the expected size of the amplification product $(9,15)$ was obtained, whereas no products were amplified from seronegative plants. Results were confirmed by cloning and partial sequencing of the PCR products (data not shown). SPCFV was not tested by RT-PCR because no sequence data were available for this virus, but the results of NCM-ELISA were clearly and repeatedly positive for the sweetpotato plants, and for I. setosa following graft transmission of the virus.

Diseases observed. Commonly observed virus-like symptoms in the surveyed fields of all districts were vein clearing, mottling, chlorotic spots, leaf distortion, stunting, purpling, leaf narrowing, and general yellowing of the entire plant.

Symptoms became pronounced in the leaves of young shoots 2 weeks after establishment in the screenhouse. Symptoms of plants co-infected with several viruses typically were more severe than in plants infected with a single virus (Fig. 4). Sweetpotato plants that tested positively only for SPFMV showed faint chlorotic spots and vein clearing (Fig. 4A). However, the plants seropositive for both SPFMV and SPCSV showed severe symptoms of leave distortion, leaf narrowing, stunting of the plant, and purpling of older leaves (i.e., the symptoms characteristic of SPVD; Fig. 4G). In contrast, it usually was not possible to discriminate with accuracy symptoms in plants seropositive for SPCSV alone from noninfected plants at an early stage of growth in the screenhouse, but purpling of mature leaves was observed in older leaves (Fig. 4C). Symptoms caused by SPFMV and SPCSV were distinguishable in I. setosa. Grafting of $I$. setosa with scions from sweetpotato plants seropositive for only SPFMV or only SPCSV caused vein chlorosis and blister- 
ing (Fig. 4F) or yellowing of leaves and reduced growth, respectively.

In sweetpotato plants infected only with SPMMV, severe clearing of the midvein developed starting from the leaf tip, and chlorotic patches along veins were exhibited (Fig. 4B). Mixed infection with SPMMV and SPCSV caused severe vein clearing (Fig. 4E) and slight stunting of the sweetpotato plants, whereas the combination of SPFMV with SPMMV induced vein chlorosis but did not interfere with normal growth of the plant. No clear symptoms were observed on plants that tested positive for SPCFV alone. Hairiness disorders also were observed in a number of plants from Bukoba and Tarime. One plant showing hairiness and midvein chlorosis tested positive for SPMMV.

\section{DISCUSSION}

This study provides novel information about incidence of viruses in sweetpotato crops in Tanzania. Four viruses, SPFMV, SPMMV, SPCSV, and SPCFV, were detected by serological methods. For SPFMV, SPMMV, and SPCSV, results on several seropositive plants were validated by RT-PCR and sequencing of the amplification products. The serological data showed that SPFMV is the most prevalent virus occurring in each of the five districts surveyed at the Lake Victoria zone and the Indian Ocean coastal zone. A high proportion of the plants with virus-like symptoms were seropositive only for SPFMV. These plants showed mild symptoms (Fig. 4A), in contrast to the severe symptoms of SPVD observed in all plants seropositive for SPFMV and SPCSV (Fig. 4G). Coinfection with SPFMV and SPCSV greatly enhances the accumulation of SPFMV in sweetpotato plants but has no detectable effect on accumulation of SPCSV (12). Therefore, detection of SPCSV in all plants displaying SPVD and no detection of SPCSV in the high number of sweetpotato plants seropositive for SPFMV and showing mild symptoms indicates that, indeed, SPCSV is relatively rare compared with SPFMV in Tanzania. Three leaves of different maturity level were tested for viruses in each sweetpotato plant established in the screenhouse; therefore, detec- tion of viruses was possible regardless of the expected differences in virus concentrations in mature leaves compared with developing leaves, as shown for SPCSV (12).

Results showed that SPVD occurs in both of the main agroecological zones surveyed but is more common at the Lake zone. These results agree with previous surveys for virus disease incidences carried out in Uganda, where co-infections with SPFMV and SPCSV are common (15). Indeed, the high incidence of SPVD seems to be a consequence of a common occurrence of SPCSV that breaks down the otherwise substantial levels of resistance to SPFMV in many East African sweetpotato cultivars $(1,11,12)$. Thus, a lower incidence of SPVD at the coastal zone of Tanzania was in accordance with the lower frequency of SPCSV there.

Planting seasons in Tanzania are determined mainly by availability of rainfall. In the Bukoba district, a highland with a humid climate at the Lake Victoria basin (Fig. 1), sweetpotato fields were interspaced between banana and coffee fields,
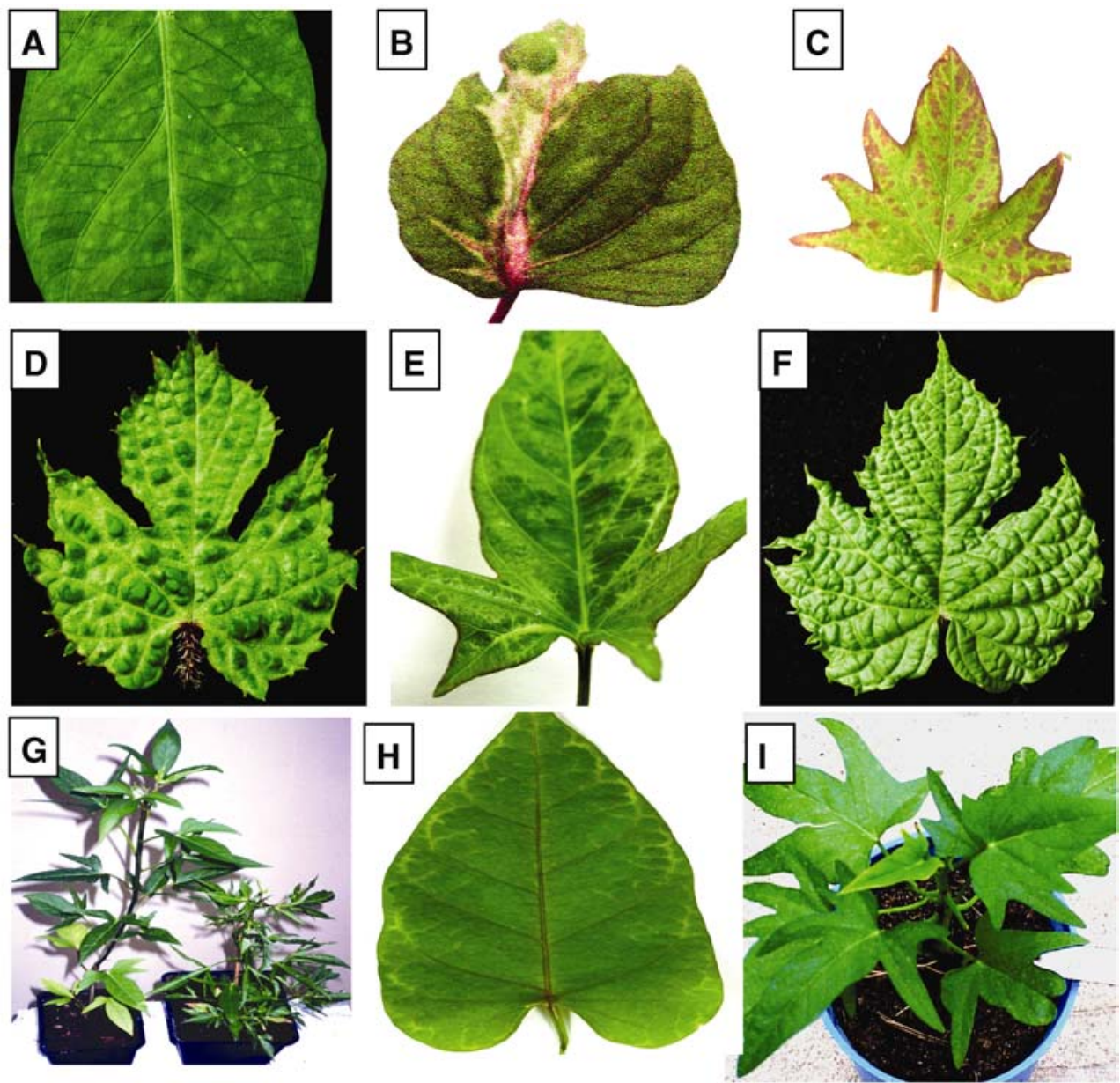

Fig. 4. Virus-associated symptoms. A, Chlorotic spots on sweetpotato cv. Mwangito infected with Sweet potato feathery mottle virus (SPFMV). B, Severe midvein clearing in sweetpotato cv. Kasinia infected with Sweet potato mild mottle virus (SPMMV). C, Leaf purpling in sweetpotato cv. Itembe infected with Sweet potato chlorotic stunt virus (SPCSV). D, Severe leaf clearing in main veins and scattered blisters on a leaf of Ipomoea setosa grafted with a scion from sweetpotato cv. Kasinia infected with SPMMV. E, Chlorosis on sweetpotato cv. Ukerewe co-infected with SPMMV and SPCSV. F, Excessive blistering on a leaf of $I$. setosa grafted with a scion from sweetpotato cv. Mwongu infected with SPFMV. G, Sweetpotato cv. Tanzania co-infected with SPFMV and SPCSV shows the typical symptoms of sweetpotato virus disease (e.g., severe stunting; healthy plant to the left). H, Virus-like vein etching along the leaf edge on sweetpotato cv. Mke wa katibu caused by an unknown agent. I, Non-virus-infected sweetpotato cv. Simama. 
and were mostly home gardens with continuous cultivation of sweetpotato. However, Tarime and Misungwi have a lowland semi-humid climate, and sweetpotato cultivation is fixed by rainfall patterns and takes place during November to February. Second cropping is sometimes practiced from April and July. The Indian Ocean costal zone has a lowland humid climate and rainfall is sufficient for sweetpotato cultivation in the Bagamoyo district (mainland) and Unguja (Zanzibar Island) throughout the year but, nevertheless, sweetpotato crops are not continuously grown. Between the cropping seasons, sweetpotato cultivars are maintained in garden plots. Apical cuttings of 15 to 40 $\mathrm{cm}$ taken from vines of mature crops commonly were used as planting materials in all the surveyed areas. In Misungwi areas away from lakeshores, plant materials can be scarce during drought. Therefore, farmers are obliged to buy them from neighboring villages, unlike in Bagamoyo and Unguja, where such materials are freely available from neighbors. Nearly all farmers interviewed in the Lake Zone and Unguja could identify diseases as a serious problem in sweetpotato. However, they did not recognize virus-like symptoms as a disease but associated viral symptoms with other factors such as drought, insect pests, and cultivar-specific behavior. Taken together, it seems that no single factor could explain why the diversity of viruses infecting sweetpotato crops in Tanzania is much wider in the Victoria Lake basin than at the Indian Ocean coastal zone, where diseased plants contained mostly SPFMV and less frequently SPCSV, but no SPMMV and SPCFV were detected.

The Lake zone in East Africa is characterized by intensive cultivation of sweetpotato in all countries, which is favored by moderately high temperatures and relatively even rainfall distribution over the year (11). Sweetpotatoes are grown throughout the year; therefore, the mature crops serve as reservoirs for vector transmission of viruses to the more recently established crops $(7,8,11)$. However, there is negligible movement of sweetpotato materials between the Lake zone and the Indian Ocean coastal zone of Tanzania. On the other hand, movement of the planting materials within the Lake zone is common. These differences may partly explain why the diversity of viruses is more limited in the coastal zone. Differences in incidence and movement of virus vectors in the two zones may be an additional factor explaining the results which needs to be explored in future studies. Our results do not rule out the possibility that other, as yet unknown or less characterized viruses not detected in this study might occur in both of the surveyed zones in Tanzania because 13 plants established in the screenhouse showed virus-like symptoms but were seronegative with the antibodies used. Further studies are required to identify the cause of symptoms in these plants.

\section{ACKNOWLEDGMENTS}

This study was funded by Sida/SAREC through the Stockholm Environmental Institute (SEI) as project no. 771402 under The East African Regional Programme and Research Network for Biotechnology, Biosafety, and Biotechnology Policy Development (BIO-EARN). We thank S. Fuentes and L. F. Salazar, International Potato Centre (CIP), Lima, Peru, for providing the antibodies for sweetpotato virus detection; and S. Mukasa for technical advice on virus detection and critical review of the manuscript.

\section{LITERATURE CITED}

1. Aritua, V., Alicai, T., Adipala, E., Carey, E. E., and Gibson, R. W. 1998. Aspects of resistance to sweet potato virus disease in sweet potato. Ann. Appl. Biol. 132:387-398.

2. Di Feo, L., Nome, S. F., Biderbost, E., Fuentes, S., and Salazar, L. F. 2000. Etiology of sweet potato chlorotic dwarf disease in Argentina. Plant Dis. 84:35-39.

3. Ewell, P. T., and Mutuura, J. 1991. Sweet potato in the food systems of Eastern and Southern Africa. Page 405-412 in: Tropical Root Crops in a Developing Economy. F. Ofori and S. K. Hahn, eds. Proc. Ninth Symp. Int. Soc. Trop. Root Crops, Accra, Ghana.

4. Feng, G., Gong, Y., and Zhang, P. 2000. Production and deployment of virus-free sweet potato in China. Crop Prot. 19:105-111.

5. Gibb, K. S., and Padovan, A. C. 1993. Detection of sweet-potato feathery mottle potyvirus in sweet-potato grown in Northern Australia using an efficient and simple assay. Intern. J. Pest Manage. 39:223-228

6. Gibson, R., Ekwamu, A., Rose, N., Thompson, G., Vetten, J., and Valkonen, J. 2003. Identification and characterisation of sweet potato viruses in East and South Africa, and assessment of host plant resistance for sustainable production. Final Report. The European Union programme for International Cooperation with Developing Countries (INCODEV), Fifth Framework Programme on Re- search, Technological Development and Demonstration Activities (FP5), Project ICA4-CT-2000-3007. National Resources Institute, Kent, UK.

7. Gibson, R. W., Mwanga, R. O. M., Kasule, S., Mpembe, I., and Carey, E. E. 1997. Apparent absence of viruses in most symptomless fieldgrown sweet potato in Uganda. Ann. Appl. Biol. 130:481-490.

8. Gutierrez, D. L., Fuentes, S., and Salazar, L. F. 2003. Sweetpotato virus disease (SPVD): Distribution, Incidence, and effect on sweetpotato yield in Peru. Plant Dis. 87:297-302.

9. IsHak, J. A., Kreuze, J. F., Johansson, A., Mukasa, S. B., Tairo, F., Abo El-Abbas, F. M., and Valkonen, J. P. T. 2003. Some molecular characteristics of three viruses in sweet potato virus disease-affected sweet potato plants in Egypt. Arch. Virol. 148:2449-2460.

10. Kapinga., R. E., Ewell, P. T., Jeremia, S. C., and Kileo, R. 1995. Sweet potato in Tanzanian Farming and Food Systems. Implications for Research. International Potato Center (CIP) Sub-Saharan Africa Regional Office, Nairobi, Kenya, and Ministry of Agriculture, Dar-esSalaam, Tanzania.

11. Karyeija, R. F., Gibson, R. W., and Valkonen, J. P. T. 1998. The significance of sweet potato feathery mottle virus in subsistence sweet potato production in Africa. Plant Dis. 82:4-15.

12. Karyeija, R. F., Kreuze, J. F., Gibson, R. W., and Valkonen, J. P. T. 2000. Synergistic interactions of a potyvirus and a phloem-limited crinivirus in sweet potato plants. Virology 269:26-36.

13. Kreuze, J. F., Karyeija, R. F., Gibson, R. W., and Valkonen, J. P. T. 2000. Comparisons of coat protein gene sequences show that East African isolates of Sweet potato feathery mottle virus form a genetically distinct group. Arch. Virol. 145:567-574.

14. Msabaha, M. A. M. 1979. Sweet potato in Tanzania. First IITA Annu. Res. Conf. International Institute of Tropical Agriculture, Ibadan, Nigeria.

15. Mukasa, S. B., Rubaihayo, P. R., and Valkonen, J. P. T. 2003. Incidence of viruses and viruslike diseases of sweetpotato in Uganda. Plant Dis. 87:329-335.

16. Mukasa, S. B., Rubaihayo, P. R., and Valkonen, J. P. T. 2003. Sequence variability within the 3'-proximal part of the Sweet potato mild mottle virus genome. Arch. Virol. 148:487496.

17. Mukasa, S. B., Tairo, F., Kullaya, A., Rubaihayo, P. R., and Valkonen, J. P. T. 2003. Coat protein sequence analysis reveals occurrence of new strains of sweet potato feathery mottle virus in Uganda and Tanzania. Virus Genes 27:49-56.

18. Schaefer, G. A., and Terry, E. R. 1976. Insect transmission of sweet potato disease agents in Nigeria. Phytopathology 66:642-645.

19. Shukla, D. D., Ward, C. W., and Brunt, A. A. 1994. The Potyviridae. CAB International, Little Hampton, UK. 